\title{
Rice (Oryza sativa L.) roots have iodate reduction activity in response to iodine
}

\author{
Shota Kato ${ }^{1 \dagger}$, Takanori Wachi ${ }^{2 \dagger}$, Kei Yoshihira ${ }^{2}$, Takuya Nakagawa $^{2}$, Akifumi Ishikawa ${ }^{2}$, Daichi Takagi ${ }^{2}$, \\ Aya Tezuka², Hideharu Yoshida ${ }^{2}$, Satoshi Yoshida ${ }^{3}$, Hitoshi Sekimoto² and Michiko Takahashi* \\ Laboratory of Plant Nutrition, Department of Plant Science, United Graduate School of Agricultural Science, Tokyo University of Agriculture and Technology, \\ Utsunomiya, Japan \\ ${ }^{2}$ Laboratory of Plant Nutrition, Department of Plant Science, Faculty of Agriculture, Utsunomiya University, Utsunomiya, Japan \\ ${ }^{3}$ Planning and Promotion Unit, Research Center for Radiation Protection, National Institute of Radiological Sciences, Chiba, Japan
}

\section{Edited by:}

Michael A. Grusak, USDA-ARS

Children's Nutrition Research

Center, USA

Reviewed by:

Yongxian Lu, Carnegie Institution for

Science, USA

Alicia Sivitz, Dartmouth College,

USA

Pierdomenico Perata, Scuola

Superiore Sant'Anna, Italy

Amedeo Alpi, University of Pisa,

Italy

*Correspondence:

Michiko Takahashi, Laboratory of

Plant Nutrition, Faculty of

Agriculture, Utsunomiya University,

350 Mine, Utsunomiya,

Tochigi 321-8505, Japan

e-mail:amichiko@

cc.utsunomiya-u.ac.jp

${ }^{\dagger}$ These authors have contributed

equally to this work.
Although iodine is not an essential nutrient for higher plants, their roots take up and transport the element. However, the exact mechanisms involved in iodine uptake and metabolism in higher plants have yet to be elucidated. In this study, we compared two cultivars differing in iodine tolerance ("Nipponbare" and "Gohyakumangoku") to increasing levels of $\mathrm{I}^{-}$and $\mathrm{IO}_{3}^{-}$in the root solutions of water-cultured rice (Oryza sativa L.). We found that $\mathrm{IO}_{3}^{-}$added to the root solutions was converted to $\mathrm{I}^{-}$in the presence of roots. lodate reduction occurred over the course of several hours. Furthermore, the iodate reduction activity of "Nipponbare" (iodine-sensitive) and "Gohyakumangoku" (iodine-tolerant) roots increased after adding $\mathrm{IO}_{3}^{-}$or $\mathrm{I}^{-}$. The roots of barley and soybean also showed iodate reduction activity and the activity responded to iodine treatment either with $\mathrm{IO}_{3}^{-}$and $\mathrm{I}^{-}$. This study suggests that plant roots biologically reduce iodate to iodide and indicates that the iodate reduction activity of roots responds to external iodine conditions.

Keywords: iodine, reduction, rice, barley, soybean, root

\section{INTRODUCTION}

Iodine, an essential element for humans, is an important component of thyroid hormones. About $15.8 \%$ of the world's population suffers from goiter, which is primarily caused by iodine deficiency. Moreover, an additional one-third of the world's population has been estimated as being at risk of iodine deficiency (De Benoist et al., 2004). One approach to addressing this problem is to increase the iodine content of the edible portions of crops. Recently, iodination of the irrigation waters or fertilizers was investigated to produce iodine-enriched crops (Cao et al., 1994; Weng et al., 2008b; Hong et al., 2009). However, growing of plants with high iodine levels in the irrigation waters is problematic as iodine-toxicity symptoms can develop under these conditions. In addition, inasmuch as iodine is not an essential nutrient for higher plants, detailed mechanisms of iodine uptake and its subsequent metabolism in higher plants have yet to be elucidated.

The major chemical form of soluble iodine in soil solutions is $\mathrm{I}^{-}$under flooded conditions (Muramatsu et al., 1989; Yuita, 1992) and $\mathrm{IO}_{3}^{-}$under non-flooded conditions (Yuita, 1992). Iodine uptake and metabolism in plants is dependent on the chemical species present in the irrigation solution. Previous reports have indicated that $\mathrm{I}^{-}$is more phytotoxic than $\mathrm{IO}_{3}^{-}$(Umaly and Poel, 1971; Mackowiak and Grossl, 1999; Zhu et al., 2003). Plants have been hypothesized to reduce $\mathrm{IO}_{3}^{-}$to $\mathrm{I}^{-}$in culture media (Böszörményi and Cseh, 1960; Muramatsu et al., 1983) and subsequently take up $\mathrm{I}^{-}$from the media (Muramatsu et al., 1983). However, to date, the reduction of $\mathrm{IO}_{3}^{-}$and the exact chemical species of iodine taken up by the plant have not been fully established.

In the present study, we investigated any changes in the chemical species of inorganic iodine $\left(\mathrm{I}^{-}\right.$and $\left.\mathrm{IO}_{3}^{-}\right)$in buffer solutions caused by rice root to illuminate the detailed mechanism of iodine uptake by higher plants. Furthermore, we examined the role of rice roots in regard to iodine reduction. From these data, we concluded that iodate reduction is a primary physiological response of rice roots to the presence of iodine.

\section{MATERIAL AND METHODS PLANT MATERIALS}

For the test of tolerance to iodine excess, three cultivars of rice were used: Oryza sativa L. cv. "Nipponbare," "Koshihikari" and "Gohyakumangoku." Rice seeds were sown to the pots with perlite. Rice plants were cultured with the culture media in a green house under natural light condition. Fourteen days-old rice seedlings were subjected to iodine treatment $\left(1 \mathrm{mmol} \mathrm{L}^{-1}\right.$ of $\mathrm{IO}_{3}^{-}$) for 17 days. Composition of the culture media ( $\mathrm{pH}$ 5.5) was $1.5 \mathrm{mmol} \mathrm{L}^{-1} \mathrm{NH}_{4} \mathrm{NO}_{3}, 1.5 \mathrm{mmol} \mathrm{L}^{-1} \mathrm{~K}_{2} \mathrm{SO}_{4}, 0.25 \mathrm{mmol} \mathrm{L}^{-1}$ 
$\mathrm{Ca}\left(\mathrm{NO}_{3}\right)_{2}, 0.5 \mathrm{mmol} \mathrm{L}^{-1} \mathrm{NH}_{4} \mathrm{H}_{2} \mathrm{PO}_{4}, 1 \mathrm{mmol} \mathrm{L}^{-1} \mathrm{MgSO}_{4}$ and adequate levels of micronutrients. The media was renewed three times a week. At the end of the iodine treatment, shoot length was measured. For the measurement of iodine concentration in shoots of soil-cultured rice, rice seedlings were subjected to iodine treatment $\left(\mathrm{IO}_{3}^{-}\right.$was mixed with the soil at $\left.1 \mathrm{mmol} \mathrm{kg} \mathrm{soil}{ }^{-1}\right)$ in the green house under natural light condition. After the $\mathrm{IO}_{3}^{-}$ treatment, shoots were harvested for the determination of iodine concentration.

For the measurement of iodate reduction activity using rice roots without iodine treatment, rice seedlings (cv. "Koshihikari") were water-cultured for 27 days in a growth chamber $\left(28 / 23^{\circ} \mathrm{C}\right.$, $12 / 12 \mathrm{~h}$ ) with culture solution ( $\mathrm{pH} 5.5)$ mentioned above. The media were renewed once a week.

For the measurement of iodate reduction activity using rice roots with iodine treatment, water-cultured 21 days-old seedlings (cv. "Nipponbare" and "Gohyakumangoku") were subjected to iodine treatment for 1 week in a temperature-controlled green house $\left(32 / 27^{\circ} \mathrm{C}, 12 / 12 \mathrm{~h}\right) . \mathrm{I}^{-}$treatment was performed at 0 , $0.025,0.25,2.5,25 \mu \mathrm{mol} \mathrm{L}-1$, and $\mathrm{IO}_{3}^{-}$treatment was at $0,0.25$, $2.5,25,50,100 \mu \mathrm{mol} \mathrm{L}^{-1}$. Iodine containing media were renewed twice a week.

For the comparison of iodate reduction activity with barley and soybean roots, water-cultured 10 days-old barley seedlings (Hordeum vulgare L. cv. "Mikamogolden") were subjected to iodine treatment in a temperature-controlled $\left(27 / 22^{\circ} \mathrm{C}, 12 / 12 \mathrm{~h}\right)$ green house under natural light condition. Water-cultured 15 days-old soybean seedlings (Glycine max cv. "Tachinagaha”) were subjected to iodine treatment in the temperature-controlled $\left(27 / 22^{\circ} \mathrm{C}, 12 / 12 \mathrm{~h}\right)$ green house under natural light condition. Twenty-one days-old rice seedlings (cv. "Gohyakumangoku") were subjected to iodine treatment in the temperature-controlled green house $\left(32 / 27^{\circ} \mathrm{C}, 12 / 12 \mathrm{~h}\right) . \mathrm{I}^{-}$treatment was performed at $0,5,10,20,50 \mu \mathrm{mol} \mathrm{L}-1$, and $\mathrm{IO}_{3}^{-}$treatment was at $0,50,100$, 200, $500 \mu \mathrm{mol} \mathrm{L}^{-1}$. Iodine containing media were renewed twice a week after the start of iodine treatment.

\section{DETERMINATION OF IODATE REDUCTION ACTIVITY}

Rice roots were rinsed with ion-exchanged water and cut at the basal parts. For the determination of iodate reduction activity using roots without iodine treatment, excised roots were immersed in Tris- $\mathrm{HCl}$ buffer $\left(50 \mathrm{mmol} \mathrm{L}^{-1}, \mathrm{pH} 8.0\right.$ ) containing $0.16 \mu \mathrm{mol} \mathrm{L}^{-1}\left(20 \mu \mathrm{g} \mathrm{L}^{-1}\right.$ as I) of $\mathrm{I}^{-}$or $\mathrm{IO}_{3}^{-}$. After $24 \mathrm{~h}$ of incubation in the dark at $20^{\circ} \mathrm{C}$, the buffer solutions were filtered $(0.2 \mu \mathrm{m})$ and frozen at $-80^{\circ} \mathrm{C}$ immediately. $\mathrm{pH}$ of assay buffer was determined to prevent loss of produced $\mathrm{I}^{-}$by automatical change $2 \mathrm{I}^{-} \rightarrow \mathrm{I}_{2}$ at lower $\mathrm{pH}$. The concentrations of $\mathrm{I}^{-}$and $\mathrm{IO}_{3}^{-}$in the buffer solutions were determined by ion chromatography and inductively coupled plasma-mass spectrometry system (IC-ICP-MS) (Yoshida et al., 2007) described as follows.

For the determination of iodate reduction activity using roots subjected to iodine treatment, excised roots were immersed to Tris- $\mathrm{HCl}\left(5 \mathrm{mmol} \mathrm{L}{ }^{-1}, \mathrm{pH} 8.0\right.$ ) containing $\mathrm{IO}_{3}^{-} 0.1 \mathrm{mmol} \mathrm{L}^{-1}$, followed by $6 \mathrm{~h}$ ' incubation at $25^{\circ} \mathrm{C}$ in the dark. After the incubation, the buffer solution was filtered $(0.2 \mu \mathrm{m})$ and frozen immediately at $-80^{\circ} \mathrm{C}$ until the measurement. Iodate reduction activity was evaluated by the amount of $\mathrm{I}^{-}$reduced from $\mathrm{IO}_{3}^{-}$by $1 \mathrm{~g}$ (FW) of excised roots per hour. $\mathrm{I}^{-}$concentration in the buffer was determined by $4,4^{\prime}$-methylenebis $(N, N$-dimethylaniline)chloramine T reaction (Yonehara et al., 1991). To evaluate the net $\mathrm{I}^{-}$concentration reduced from $\mathrm{IO}_{3}^{-}$by excised roots, the concentration of $\mathrm{I}^{-}$in the $\mathrm{IO}_{3}^{-}$-free buffer incubated with excised roots was also determined as $\mathrm{I}^{-}$derived from excised roots during incubation, and subtracted from $\mathrm{I}^{-}$concentration in the $\mathrm{IO}_{3}^{-}$buffer incubated with excised roots.

\section{THE SEPARATE DETERMINATION OF CONCENTRATION OF I- AND $10_{3}^{-}$ IN THE BUFFER SOLUTIONS}

The concentrations of $\mathrm{I}^{-}$and $\mathrm{IO}_{3}^{-}$in the buffer solutions were determined by ion chromatography (IC: IC7000S, Column: EXCELPAK ICS-A23, Yokogawa Analytical Systems Inc.) and inductively coupled plasma-mass spectrometry (7500, Agilent) system (IC-ICP-MS) (Yoshida et al., 2007). The detection limit of the system was $8 \mathrm{nmol} \mathrm{L}-1$ of $\mathrm{I}^{-}$and $\mathrm{IO}_{3}^{-}$.

\section{DETERMINATION OF TOTAL IODINE CONCENTRATION IN PLANT TISSUE}

About $0.1 \mathrm{~g}$ of plant samples (shoots and roots) dried at $80^{\circ} \mathrm{C}$ were digested by $25 \%$ tetramethyl ammonium hydroxide (TAMAPURE-AA TMAH, Tama Chemicals Co., Ltd.) in a $6 \mathrm{ml}$ PFA vial (Savillex Co.) overnight at $80^{\circ} \mathrm{C}$ (Tagami et al., 2006). Concentration of ${ }^{127} \mathrm{I}$ in the solution was determined by ICP-MS (7500, Agilent).

\section{RESULTS \\ TOLERANCE AMONG THREE RICE CULTIVARS TO HIGH SOLUTION LEVELS OF IODINE}

To confirm the tolerance levels of our three rice cultivars, "Nipponbare," "Koshihikari" and "Gohyakumangoku" to high iodine concentrations, we treated each cultivar with $1 \mathrm{mmol} \mathrm{L}^{-1}$ $\mathrm{IO}_{3}^{-}$. Figure 1A shows plants treated with $\mathrm{IO}_{3}^{-}$in the pots filled with perlite and culture media. Visible symptoms of iodine toxicity were observed in all three cultivars. The basal part of the stem developed a reddish-brown color. In addition, reddishbrown puncta were observed in the lower leaves. The symptoms were the most visible in "Nipponbare" and the least apparent in "Gohyakumangoku." Chlorosis was also observed in leaves of both "Nipponbare" and "Gohyakumangoku." Figure 1B shows the shoot length of the three rice cultivars treated with or without $\mathrm{IO}_{3}^{-}$for 17 days. In our $\mathrm{IO}_{3}^{-}$treatment, the average shoot lengths of "Nipponbare," "Koshihikari" and "Gohyakumangoku" were 145, 176, and $193 \mathrm{~mm}$, respectively.

Figure 1C illustrates the tolerance of levels among three cultivars grown with $\mathrm{IO}_{3}^{-}$-mixed soil under flooded conditions. Growth retardation by iodine treatment was most apparent in "Nipponbare." Iodine concentration in shoots of "Nipponbare" was 1.7 and 1.8 times as much as that of "Koshihikari" and "Gohyakumangoku," respectively (Figure 1D). The tolerance levels among the three cultivars to excess iodine in $\mathrm{I}^{-}$treatment were similar to those in $\mathrm{IO}_{3}^{-}$treatment (Figure A1A). Based on these results, "Nipponbare" was used as our iodine-sensitive cultivar and "Gohyakumangoku" as our iodine-tolerant cultivar in this study. 

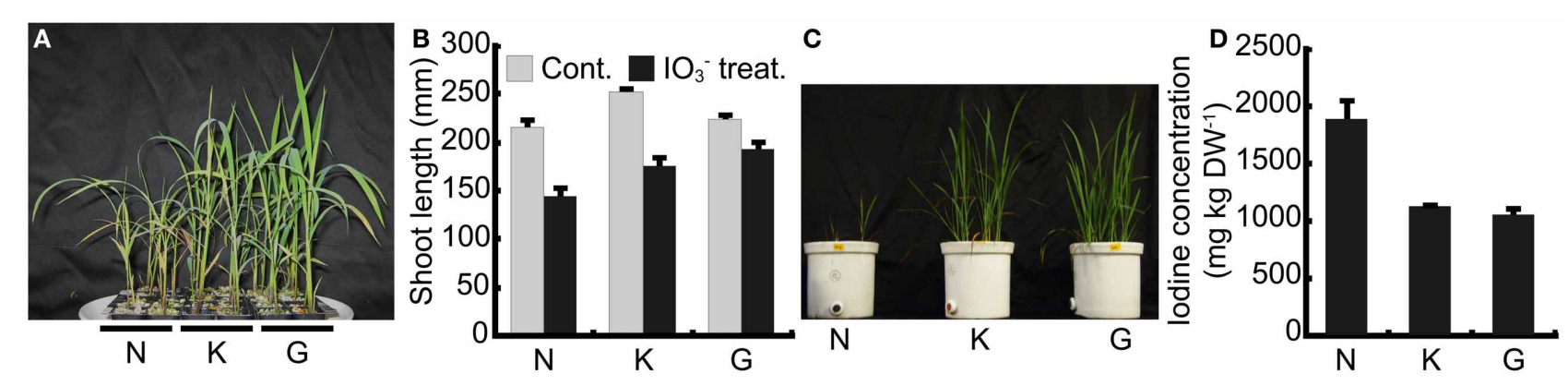

FIGURE 1 | Tolerance among three rice cultivars, "Nipponbare" (N), "Koshihikari" (K), and "Gohyakumangoku" (G) to iodine excess. (A) Rice plants treated with $\mathrm{IO}_{3}^{-}$. Rice plants were cultured in pots filled with perlite and Kasugai's nutrient solution ( $\mathrm{pH}$ 5.5) containing $\mathrm{IO}_{3}^{-}$. (B) Shoot length of rice plants treated with or without $\mathrm{IO}_{3}^{-}$. Cont.: rice plants treated without
$1 \mathrm{O}_{3}^{-}, 1 \mathrm{O}_{3}^{-}$treat.: rice plants treated with $1 \mathrm{O}_{3}^{-}$. Data are mean \pm standard error $(n=6)$. (C) Shoots of soil-cultured rice cultivars after the iodine treatment. Rice seedlings were grown in 1/5000a Wagner pots with soil mixed with $\mathrm{IO}_{3}^{-}$. (D) Concentration of iodine in the shoots of soil-cultured rice (C) after the $\mathrm{IO}_{3}^{-}$treatment. Data are mean \pm standard error $(n=4)$.

\section{IODATE REDUCTION BY RICE ROOTS}

To investigate any changes in chemical species of iodine caused by rice roots, excised rice roots were immersed in solutions of $\mathrm{I}^{-}$or $\mathrm{IO}_{3}^{-}$. The roots of "Koshihikari" were used because it showed medium-tolerance to iodine excess between "Nipponbare" and "Gohyakumangoku." Figure 2A shows the concentrations of $\mathrm{I}^{-}$or $\mathrm{IO}_{3}^{-}$in the solutions of $\mathrm{I}^{-}$or $\mathrm{IO}_{3}^{-}$after a 24-h incubation period with or without root tissue. The concentrations of $\mathrm{I}^{-}$or $\mathrm{IO}_{3}^{-}$were not changed in the solutions of $\mathrm{I}^{-}$or $\mathrm{IO}_{3}^{-}$without roots after the incubation. The concentration of $\mathrm{I}^{-}$was also unchanged in the $\mathrm{I}^{-}$solution with roots after the incubation. On the other hand, the concentration of $\mathrm{I}^{-}$was increased in the $\mathrm{IO}_{3}^{-}$solution with roots after the incubation.

A time course of changes in chemical species of iodine was also analyzed in the solutions of $\mathrm{IO}_{3}^{-}$with roots (Figure $2 \mathbf{B}$ ). The concentration of $\mathrm{IO}_{3}^{-}$in $\mathrm{IO}_{3}^{-}$solution was decreased over $24 \mathrm{~h}$. Meanwhile, $\mathrm{I}^{-}$concentrations in $\mathrm{IO}_{3}^{-}$solution were increased over the same time period. This result indicated that the chemical form of iodine was changed between $\mathrm{I}^{-}$and $\mathrm{IO}_{3}^{-}$and suggested that almost all the $\mathrm{IO}_{3}^{-}$in the solution were reduced to $\mathrm{I}^{-}$by rice roots.

\section{EFFECT OF IODINE TREATMENT ON THE GROWTH OF AN IODINE-SENSITIVE AND AN IODINE-TOLERANT CULTIVAR}

Figure 3 shows the third leaves of "Nipponbare" and "Gohyakumangoku" 1 week after $\mathrm{IO}_{3}^{-}$treatment at increasing iodine concentrations. At the iodine concentration below $25 \mu \mathrm{mol} \mathrm{L}{ }^{-1} \mathrm{IO}_{3}^{-}$, visible iodine-toxicity symptoms were not observed in the shoots of "Nipponbare." However, mild chlorosis and reddish-brown puncta were observed in the shoot of "Nipponbare" at $50 \mu \mathrm{mol} \mathrm{L}{ }^{-1} \mathrm{IO}_{3}^{-}$, and severe symptoms at $100 \mu \mathrm{mol} \mathrm{L}{ }^{-1} \mathrm{IO}_{3}^{-}$. Conversely, visible changes were not observed in the shoots of "Gohyakumangoku" at all concentrations of the $\mathrm{IO}_{3}^{-}$treatment.

Table 1 shows the length and fresh weight of both the shoots and roots of "Nipponbare" and "Gohyakumangoku" after $\mathrm{IO}_{3}^{-}$ treatment. The shoot length of "Nipponbare" was decreased in our $\mathrm{IO}_{3}^{-}$treatment in a concentration-dependent manner. The

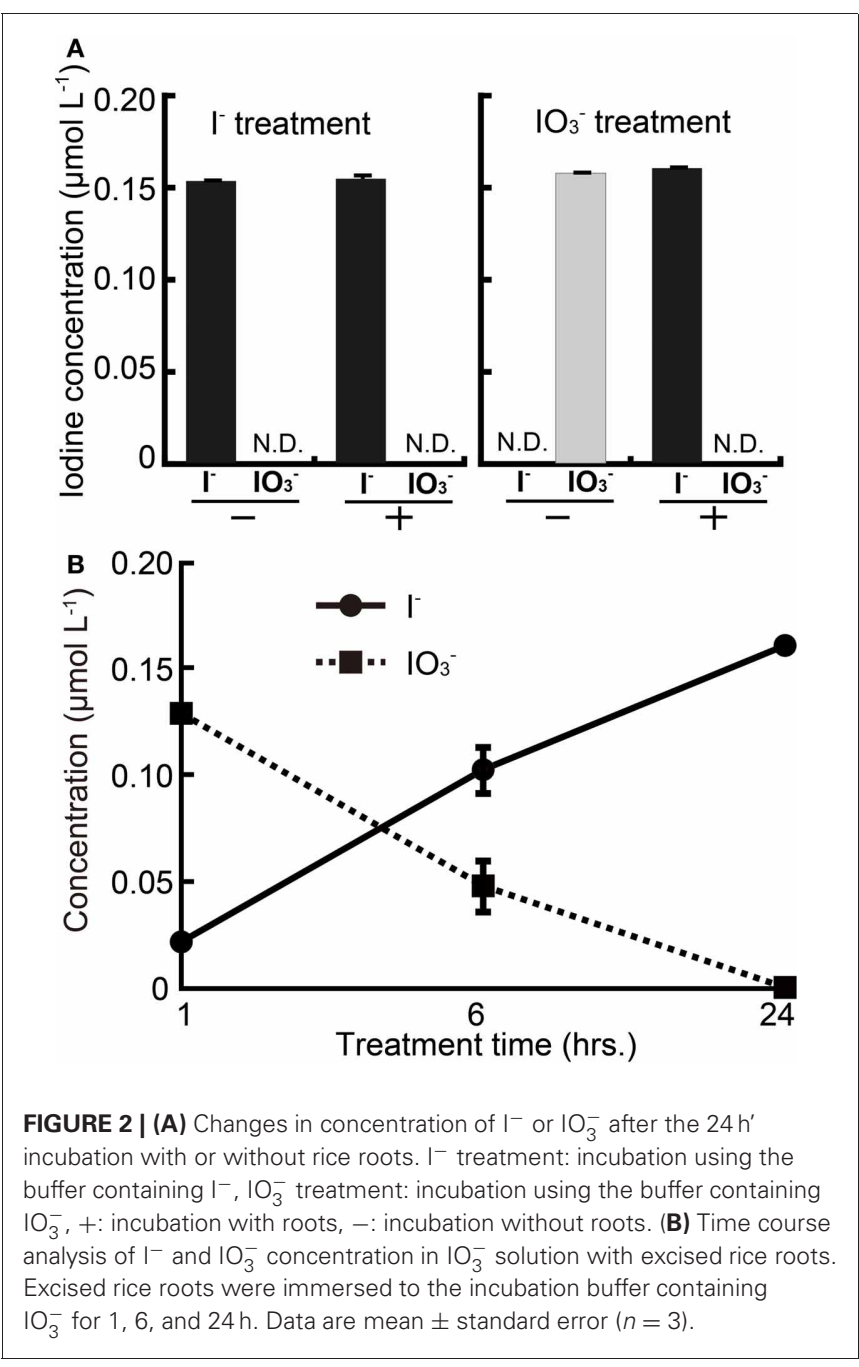

shoot length of "Nipponbare" at $100 \mu \mathrm{mol} \mathrm{L} \mathrm{L}^{-1} \mathrm{IO}_{3}^{-}$was $85 \%$ that of the control. Significant changes were not observed in shoot fresh weight, root length, or root fresh weight of "Nipponbare" by $\mathrm{IO}_{3}^{-}$treatment. The length and fresh weight of the shoot and root 


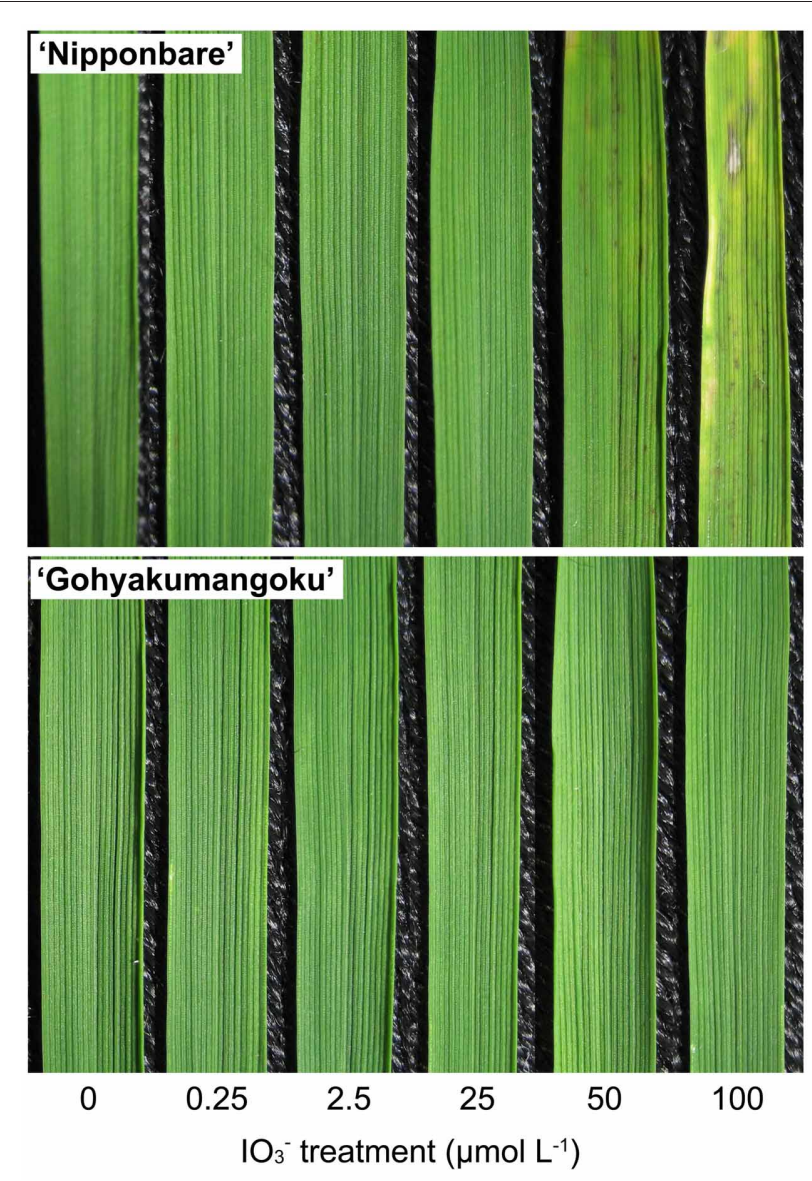

FIGURE 3 | The third leaves of "Nipponbare" and "Gohyakumangoku" after the $\mathrm{IO}_{3}^{-}$treatment at varying concentration. Rice seedling were treated with $\mathrm{IO}_{3}^{-}$at $0,0.25,2.5,25,50,100 \mu \mathrm{mol} \mathrm{L}^{-1}$.

of "Gohyakumangoku" were not significantly affected by $\mathrm{IO}_{3}^{-}$ treatment.

The third leaves of "Nipponbare" and "Gohyakumangoku" plants subjected to varying $\mathrm{I}^{-}$concentrations for 7 days are shown in Figure 4. In the leaves of "Nipponbare," mild and severe iodine-toxicity symptoms appeared in our 2.5 and $25 \mu \mathrm{mol}$ $\mathrm{L}^{-1} \mathrm{I}^{-}$treatments, respectively. When subjected to $25 \mu \mathrm{mol} \mathrm{L}{ }^{-1}$ of $\mathrm{I}^{-}$treatment, the leaves of "Gohyakumangoku" plants also exhibited visible iodine-toxicity symptoms.

The growth of "Nipponbare" shoots decreased in the plants grown under $\mathrm{I}^{-}$treatment. This decrease was also in a concentration-dependent manner (Table 2A). In our 2.5 and $25 \mu \mathrm{mol} \mathrm{L}^{-1}$ treatments, we measured a $20 \%$ and $26 \%$ decrease, respectively, in shoot length compared to the controls. The shoot fresh weight was only $70 \%$ and $58 \%$ that of the controls at 2.5 and $25 \mu \mathrm{mol} \mathrm{L}^{-1} \mathrm{I}^{-}$, respectively. In the case of "Nipponbare" root growth, the fresh weight of the roots under 2.5 and $25 \mu \mathrm{mol} \mathrm{L}{ }^{-1} \mathrm{I}^{-}$treatment decreased to 68 and $58 \%$, respectively, of the control value. Meanwhile, root length did not appear to be significantly affected by $\mathrm{I}^{-}$treatment. With respect to our tolerant cultivar, we found no significant effects on
Table 1 | Effect of the $\mathrm{IO}_{3}^{-}$treatment on length and fresh weight of shoots and roots of A "Nipponbare" and B "Gohyakumangoku."

\begin{tabular}{|c|c|c|c|c|}
\hline \multirow[t]{2}{*}{$\begin{array}{l}\mathrm{IO}_{3}^{-} \text {treatment } \\
\left(\mu \mathrm{mol} \mathrm{L}^{-1}\right)\end{array}$} & \multicolumn{2}{|c|}{$\begin{array}{l}\text { Length } \\
\text { (mm) }\end{array}$} & \multicolumn{2}{|c|}{$\begin{array}{c}\text { Fresh } \\
\text { weight (g) }\end{array}$} \\
\hline & Shoot & Root & Shoot & Root \\
\hline \multicolumn{5}{|l|}{ (A) } \\
\hline 0 & $292 \pm 5^{a, b}$ & $116 \pm 8^{a}$ & $1.00 \pm 0.06^{a, b}$ & $0.28 \pm 0.02^{a}$ \\
\hline 0.25 & $290 \pm 12^{a, b}$ & $112 \pm 4^{a}$ & $1.06 \pm 0.07^{a, b}$ & $0.29 \pm 0.03^{\circ}$ \\
\hline 2.5 & $301 \pm 3^{a}$ & $106 \pm 5^{a}$ & $1.09 \pm 0.06^{a}$ & $0.29 \pm 0.02^{a}$ \\
\hline 25 & $287 \pm 7^{a, b}$ & $114 \pm 2^{a}$ & $1.04 \pm 0.02^{\mathrm{a}, \mathrm{b}}$ & $0.30 \pm 0.01^{a}$ \\
\hline 50 & $260 \pm 11^{b, c}$ & $120 \pm 4^{a}$ & $0.84 \pm 0.04^{b}$ & $0.25 \pm 0.01^{a}$ \\
\hline 100 & $249 \pm 4^{c}$ & $122 \pm 2^{a}$ & $0.92 \pm 0.05^{a, b}$ & $0.25 \pm 0.01^{a}$ \\
\hline \multicolumn{5}{|l|}{ (B) } \\
\hline 0 & $297 \pm 8^{a}$ & $142 \pm 5^{a}$ & $1.27 \pm 0.07^{a}$ & $0.37 \pm 0.02^{a}$ \\
\hline 0.25 & $297 \pm 3^{a}$ & $131 \pm 2^{a}$ & $1.21 \pm 0.07^{a}$ & $0.32 \pm 0.02^{a}$ \\
\hline 2.5 & $318 \pm 16^{a}$ & $132 \pm 5^{a}$ & $1.23 \pm 0.03^{\mathrm{a}}$ & $0.37 \pm 0.01^{\mathrm{a}}$ \\
\hline 25 & $308 \pm 2^{a}$ & $138 \pm 4^{a}$ & $1.18 \pm 0.04^{\mathrm{a}}$ & $0.34 \pm 0.01^{\mathrm{a}}$ \\
\hline 50 & $305 \pm 2^{\mathrm{a}}$ & $133 \pm 5^{a}$ & $1.27 \pm 0.07^{a}$ & $0.41 \pm 0.03^{\circ}$ \\
\hline 100 & $302 \pm 3^{a}$ & $144 \pm 4^{a}$ & $1.19 \pm 0.03^{\mathrm{a}}$ & $0.37 \pm 0.02^{a}$ \\
\hline
\end{tabular}

Data in the columns are mean \pm standard error $(n=5)$. Values in each column followed by the same letter are not significantly different (Tukey's multiple range test, $P<0.05$ ).

length and fresh weight by $\mathrm{I}^{-}$treatment in both shoot and roots (Table 2B).

\section{EFFECT OF IODINE TREATMENTS ON IODATE REDUCTION ACTIVITY IN ROOT TISSUE}

To investigate the effect of iodine in rhizosphere on iodate reduction activity in root tissue, iodate reduction activity was measured after treatment with two kinds of species of iodine, $\mathrm{IO}_{3}^{-}$and $\mathrm{I}^{-}$, at varying concentrations.

Figure 5A shows the iodate reduction activity of roots of "Nipponbare" and "Gohyakumangoku" treated with $\mathrm{IO}_{3}^{-}$for 7 days at increasing concentrations. Iodate reduction by the roots was higher in "Nipponbare" than in "Gohyakumangoku" at all concentrations tested. Iodate reduction increased in "Nipponbare" treated with $\mathrm{IO}_{3}^{-}$. Iodate reduction increased in a concentration-dependent manner, even at concentrations resulting in the appearance of symptoms indicating iodine toxicity. Iodate reduction activity increased up to 2.8 -fold at $100 \mu \mathrm{mol}$ $\mathrm{L}^{-1} \mathrm{IO}_{3}^{-}$. On the other hand, root iodate reduction activity did not increase at concentrations higher than $2.5 \mu \mathrm{mol} \mathrm{L}{ }^{-1} \mathrm{IO}_{3}^{-}$in the "Gohyakumangoku" cultivar. However, at $2.5 \mu \mathrm{mol} \mathrm{L}^{-1} \mathrm{IO}_{3}^{-}$, reduction activity increased 1.6 -fold.

Iodine concentrations in both the shoots and roots of "Nipponbare" and "Gohyakumangoku" after $\mathrm{IO}_{3}^{-}$treatment are shown in Figures 5B, C, respectively. The concentrations of iodine in the shoots and roots of both cultivars increased with $\mathrm{IO}_{3}^{-}$treatment in a concentration-dependent manner. The difference in the shoot iodine concentrations between the two cultivars was magnified at the highest iodine treatment. The shoot iodine concentrations were higher in the shoots of "Gohyakumangoku." 


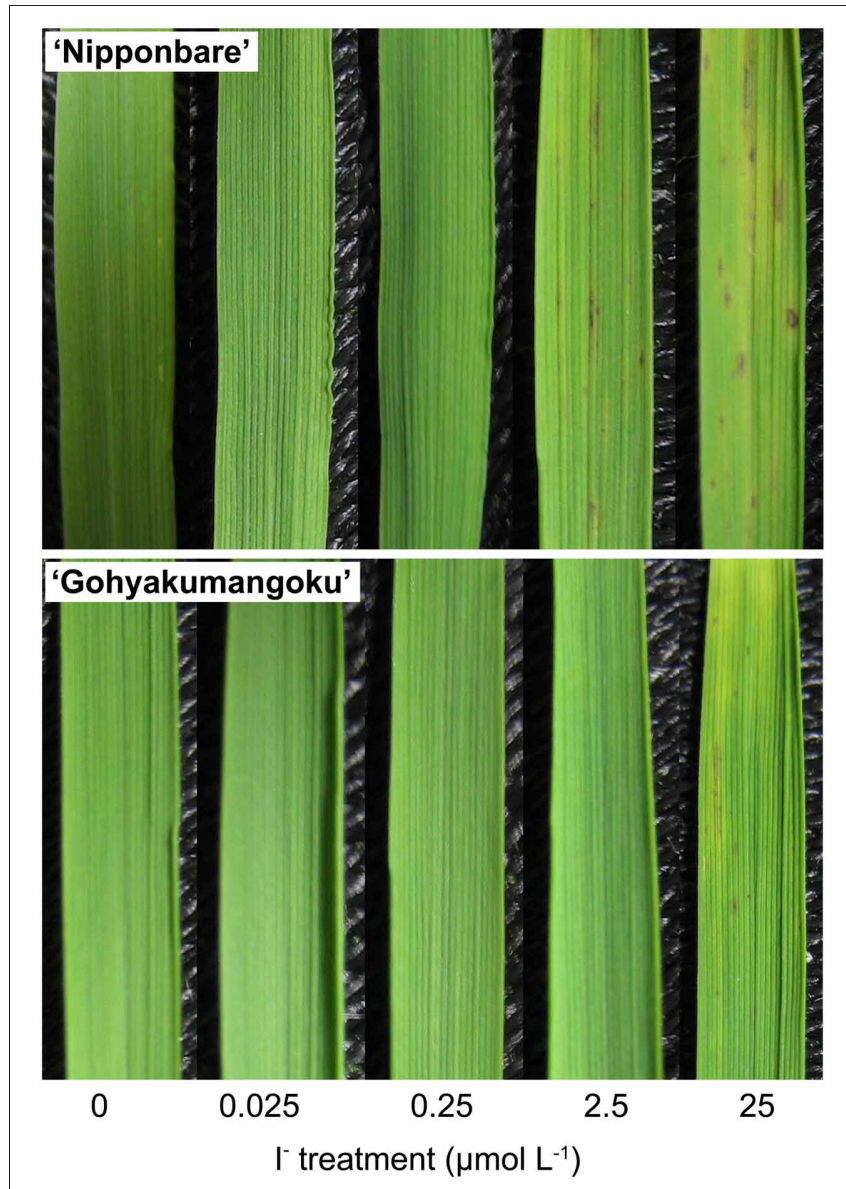

FIGURE 4 | The third leaves of "Nipponbare" and "Gohyakumangoku" after the $\mathrm{I}^{-}$treatment at varying concentration. Rice seedlings were treated with $\mathrm{I}^{-}$at $0,0.025,0.25,2.5,25 \mu \mathrm{mol} \mathrm{L}^{-1}$.

Unexpectedly, we found no significant difference in iodine concentration in the roots of our two cultivars.

Root iodate reduction activities of rice treated with $\mathrm{I}^{-}$are shown in Figure 6A. Root iodate reduction was higher in "Nipponbare" at all concentrations tested. Even at concentrations resulting in iodine-toxicity symptoms, we found that root iodate reduction increased twofold in "Nipponbare." Our tolerant cultivar, "Gohyakumangoku" also demonstrated an increase in reduction activity due to $\mathrm{I}^{-}$treatment in a concentration-dependent manner. However, reduction activity decreased at treatment levels resulting in toxicity symptoms.

Figures 6B, C shows the total iodine concentrations in both the shoot and roots of rice plants after 7 days of $\mathrm{I}^{-}$treatment. The concentrations of iodine in shoots and roots of both cultivars increased in a concentration-dependent manner with $\mathrm{I}^{-}$treatment. Also, we found that the iodine levels were higher in the shoots and lower in the roots of "Gohyakumangoku" than those of "Nipponbare." The difference in the concentration levels in these tissues between the two cultivars increased in a concentration-dependent manner with $\mathrm{I}^{-}$ treatment. At $25 \mu \mathrm{mol} \mathrm{L}^{-1} \mathrm{I}^{-}$, the iodine concentrations in the
Table 2 | Effect of the $\mathrm{I}^{-}$treatment on length and fresh weight of shoots and roots of A "Nipponbare" and B " Gohyakumangoku."

\begin{tabular}{|c|c|c|c|c|}
\hline \multirow[t]{2}{*}{ 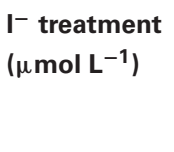 } & \multicolumn{2}{|c|}{$\begin{array}{l}\text { Length } \\
\text { (mm) }\end{array}$} & \multicolumn{2}{|c|}{$\begin{array}{c}\text { Fresh } \\
\text { weight }(g)\end{array}$} \\
\hline & Shoot & Root & Shoot & Root \\
\hline \multicolumn{5}{|l|}{ (A) } \\
\hline 0 & $261 \pm 12^{\mathrm{a}}$ & $137 \pm 8^{a}$ & $0.89 \pm 0.04^{a}$ & $0.40 \pm 0.02^{\mathrm{a}}$ \\
\hline 0.025 & $255 \pm 7^{a}$ & $145 \pm 14^{a}$ & $0.87 \pm 0.03^{a}$ & $0.37 \pm 0.01^{a, b}$ \\
\hline 0.25 & $235 \pm 4^{a, b}$ & $135 \pm 11^{\mathrm{a}}$ & $0.83 \pm 0.05^{a}$ & $0.33 \pm 0.01^{b}$ \\
\hline 2.5 & $209 \pm 3^{b, c}$ & $112 \pm 6^{a}$ & $0.62 \pm 0.02^{b}$ & $0.27 \pm 0.01^{c}$ \\
\hline 25 & $193 \pm 3^{c}$ & $131 \pm 7^{a}$ & $0.52 \pm 0.03^{b}$ & $0.23 \pm 0.01^{c}$ \\
\hline \multicolumn{5}{|l|}{ (B) } \\
\hline 0 & $219 \pm 5^{a}$ & $110 \pm 2^{a, b}$ & $0.70 \pm 0.02^{a-c}$ & $0.32 \pm 0.01^{\mathrm{a}}$ \\
\hline 0.025 & $223 \pm 4^{a}$ & $111 \pm 3^{a, b}$ & $0.72 \pm 0.02^{a, b}$ & $0.31 \pm 0.00^{a}$ \\
\hline 0.25 & $239 \pm 9^{a}$ & $108 \pm 3^{a, b}$ & $0.76 \pm 0.02^{\mathrm{a}}$ & $0.33 \pm 0.01^{a}$ \\
\hline 2.5 & $230 \pm 6^{a}$ & $124 \pm 6^{a}$ & $0.66 \pm 0.02^{b, c}$ & $0.30 \pm 0.00^{a}$ \\
\hline 25 & $237 \pm 5^{a}$ & $105 \pm 3^{b}$ & $0.62 \pm 0.03^{c}$ & $0.30 \pm 0.01^{a}$ \\
\hline
\end{tabular}

Data in the columns are mean \pm standard error $(n=6)$. Values in each column followed by the same letter are not significantly different (Tukey's multiple range test, $P<0.05$ ).

shoots of "Gohyakumangoku" was 1.8 times greater than that of "Nipponbare."

Figure 7 shows the iodate reduction activity of roots of "Nipponbare" and "Gohyakumangoku" treated with 0 and $100 \mu \mathrm{mol} \mathrm{L}^{-1}$ of $\mathrm{IO}_{3}^{-}$for 7 days. Iodate reduction activity of roots was increased with age, and induced apparently by 7 days' $\mathrm{IO}_{3}^{-}$ treatment.

\section{IODATE REDUCTION ACTIVITY IN ROOT TISSUE OF BARLEY AND SOYBEAN}

To compare these phenomena of rice with those of upland crops, iodate reduction activity of roots was investigated in barley and soybean. Barley and soybean showed also iodate reduction activity (Figures $\mathbf{8 A}, \mathbf{9 A}$ ). In $\mathrm{IO}_{3}^{-}$treatment, iodate reduction activity was the highest in rice among these three plant species (Figure 8A). Iodine concentrations in the shoots and roots of rice were higher than those of barley and soybean (Figure 8B). In $\mathrm{I}^{-}$treatment, the iodate reduction activity and iodine concentrations in the shoots and roots were the highest in barley, and the lowest in soybean (Figure 9).

\section{DISCUSSION}

Rice plants often display iodine-toxicity symptoms, known as reclamation Akagare disease or Akagare type III, when grown in upland fields that have been converted to lowland fields in some volcanic ash soils (Baba et al., 1964; Tensho, 1970; Watanabe and Tensho, 1970). In soil solutions, the major chemical species of soluble iodine are generally thought to be $\mathrm{I}^{-}$under flooded conditions (Muramatsu et al., 1989; Yuita, 1992) and $\mathrm{IO}_{3}^{-}$under non-flooded conditions (Yuita, 1992). At similar concentrations, $\mathrm{I}^{-}$appears to be more phytotoxic than $\mathrm{IO}_{3}^{-}$(Umaly and Poel, 1971; Mackowiak and Grossl, 1999; Zhu et al., 2003; Weng et al., 


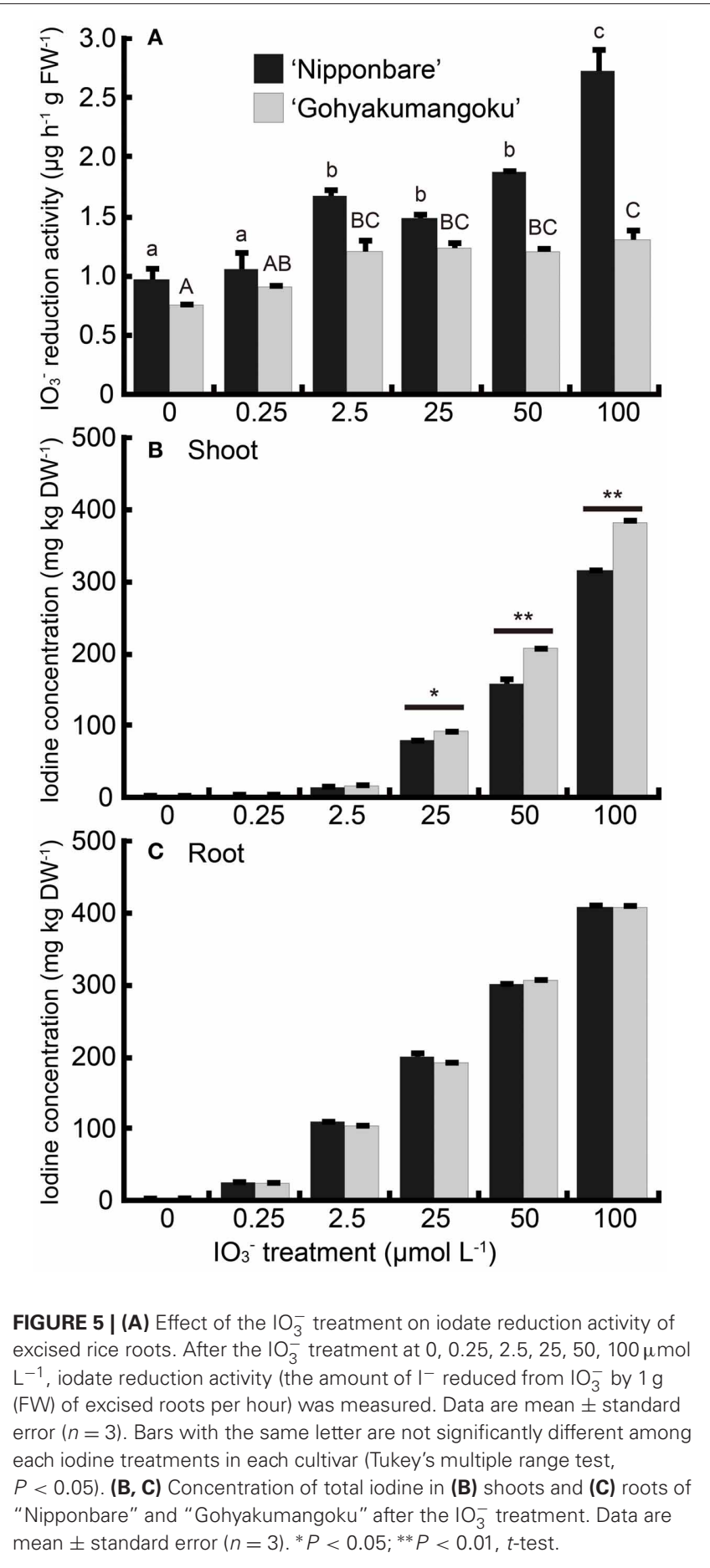

2008a). Böszörményi and Cseh (1960) suggested that $\mathrm{IO}_{3}^{-}$is reduced to $\mathrm{I}^{-}$electrochemically before uptake by wheat roots. Muramatsu et al. (1983) reported that the Komatsuna plant, Brassica rapa var. pervidis, can accelerate the conversion of $\mathrm{IO}_{3}^{-}$ to $\mathrm{I}^{-}$in culture solution. Together, these reports indicate that in culture media, plants can reduce $\mathrm{IO}_{3}^{-}$to $\mathrm{I}^{-}$and would take up $\mathrm{I}^{-}$. Recently, Yamada et al. (2005) further proposed that rice roots might even take up $\mathrm{I}_{2}$ oxidized from $\mathrm{I}^{-}$.

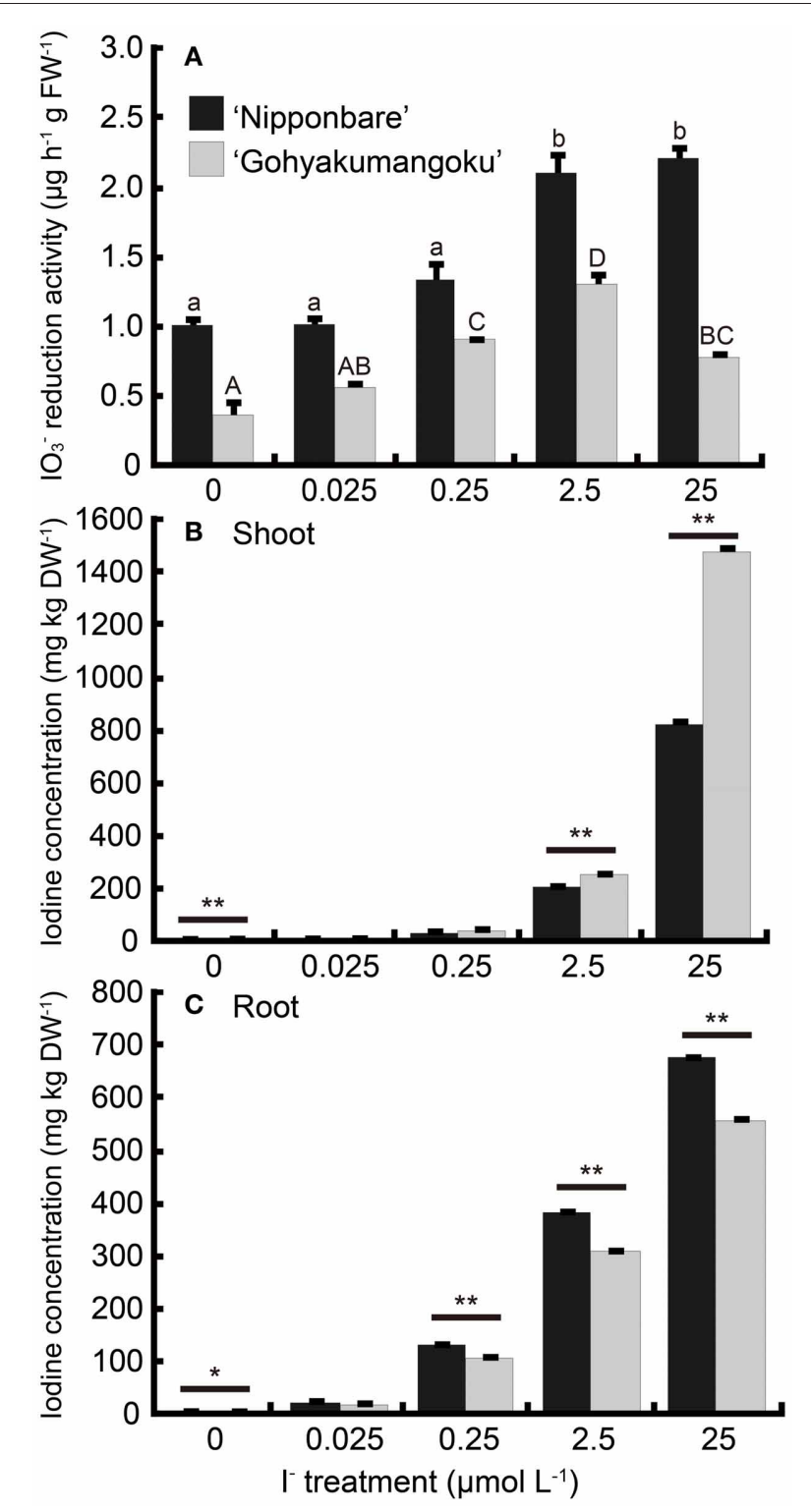

FIGURE 6 | (A) Effect of the $1^{-}$treatment on iodate reduction activity of excised rice roots. After the $\mathrm{I}^{-}$treatment at $0,0.025,0.25,2.5,25 \mu \mathrm{mol}$ $\mathrm{L}^{-1}$, iodate reduction activity was measured. Data are mean \pm standard error $(n=3)$. Bars with the same letter are not significantly different among each iodine treatments in each cultivar (Tukey's multiple range test, $P<0.05)$. (B, C) Concentration of total iodine in (B) shoots and $(\mathbf{C})$ roots of

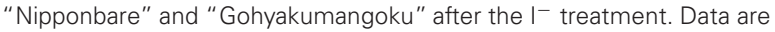
mean \pm standard error $(n=3)$. ${ }^{*} P<0.05$; ${ }^{* *} P<0.01$, $t$-test.

To date, however, whether plant roots physiologically function to change the chemical species of iodine in the rhizosphere remains unclear. To address this question, we performed a set of experiments aimed at investigating the role, if any, of rice roots in changing the chemical species of iodine. Additionally, we examined any changes occurring in the iodate reduction activity of roots by the presence of external iodine. 


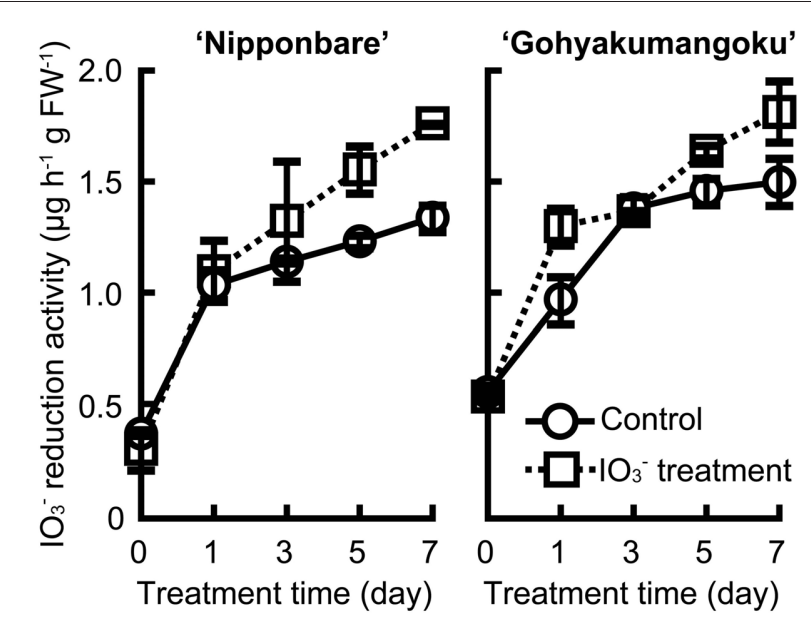

FIGURE 7 | Effect of the $1 \mathrm{O}_{3}^{-}$treatment time on iodate reduction activity of excised rice roots. Rice seedlings (cv. "Nipponbare" and "Gohyakumangoku") were subjected to 0 and $100 \mu \mathrm{mol} \mathrm{L}{ }^{-1}$ of $\mathrm{IO}_{3}^{-}$for 0,1 , 3,5 , and 7 days. After the $1 \mathrm{O}_{3}^{-}$treatment, iodate reduction activity was measured. Data are mean \pm range $(n=2)$ Control: iodate reduction activity of rice roots treated without $\mathrm{IO}_{3}^{-}, \mathrm{IO}_{3}^{-}$treatment: iodate reduction activity of rice roots treated with $\mathrm{IO}_{3}^{-}$.

\section{DIFFERENCES IN IODINE TOLERANCE IN RICE}

To confirm iodine tolerance among rice cultivars, we selected three rice cultivars and cultured them under the excess condition of two forms of iodine, i.e., iodide $\left(\mathrm{I}^{-}\right)$and iodate $\left(\mathrm{IO}_{3}^{-}\right)$. Our results clearly demonstrate the degree of tolerance to excess iodine ( $\mathrm{I}^{-}$and $\mathrm{IO}_{3}^{-}$) among these cultivars: "Nipponbare" < "Koshihikari" < "Gohyakumangoku" (Figures 1, A1). These results are in agreement with those reported by Yamada et al. (2006). However, it was considered that the tolerance levels among three rice cultivars to excess iodine had no obvious relation to iodine concentration in shoots as described below.

\section{IODATE REDUCTION BY ROOT TISSUE}

To elucidate whether rice roots convert $\mathrm{IO}_{3}^{-}$or $\mathrm{I}^{-}$to some other chemical species of iodine, concentrations of $\mathrm{IO}_{3}^{-}$or $\mathrm{I}^{-}$ were determined in iodine solutions incubated with the excised roots of "Koshihikari." Almost all of $\mathrm{IO}_{3}^{-}$added to the buffer was reduced to $\mathrm{I}^{-}$by the excised roots during a 24 -h incubation period. However, the concentration of $\mathrm{I}^{-}$was unchanged in the $\mathrm{I}^{-}$solution with roots after the incubation (Figure $2 \mathrm{~A}$ ). In addition, our time-course analysis indicated that iodate reduction occurred over the course of several hours (Figure 2B). Collectively, these results indicate that rice roots have the ability

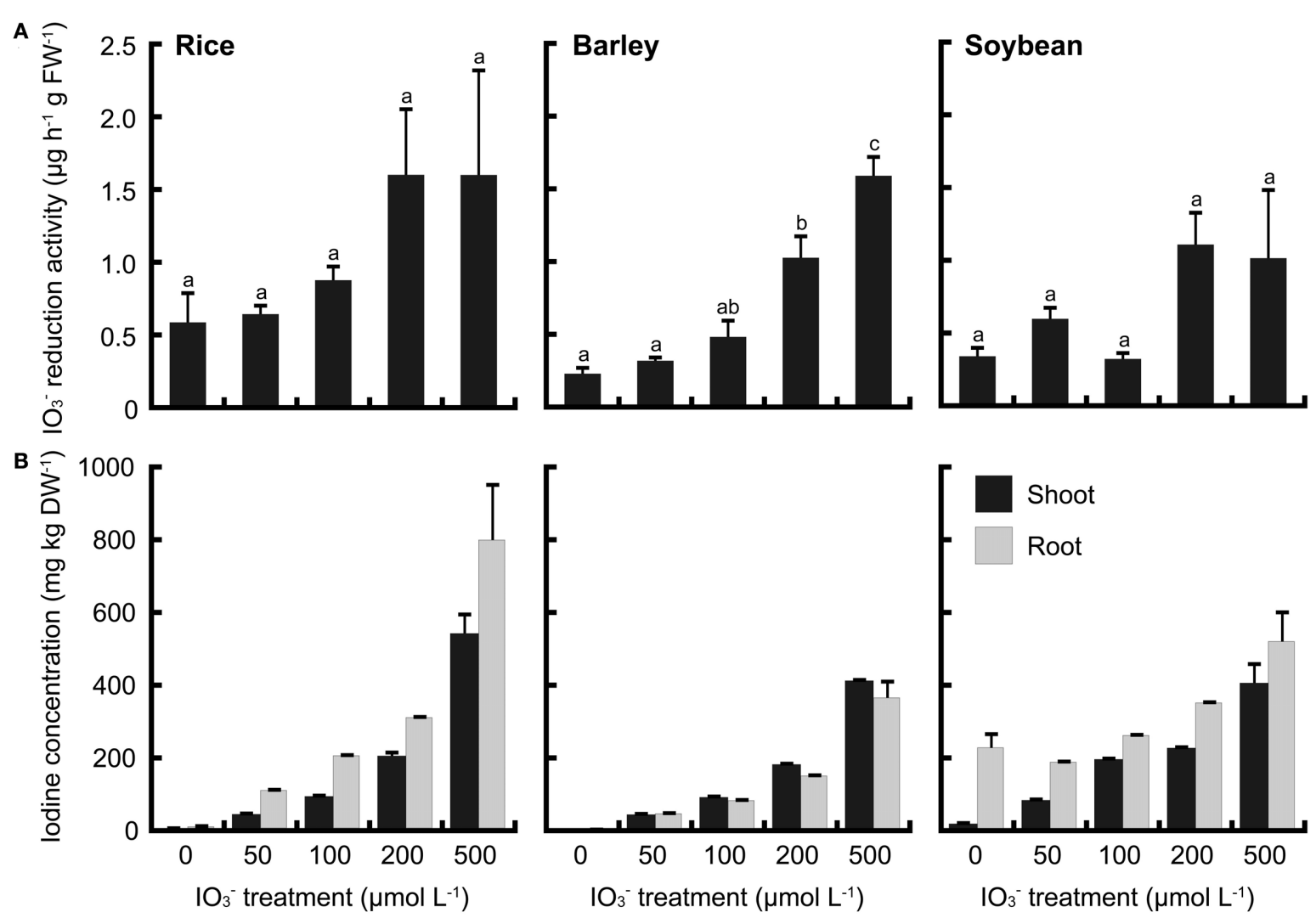

FIGURE 8 | (A) Effect of the $1 \mathrm{O}_{3}^{-}$treatment on iodate reduction activity of excised roots in rice, barley and soybean. After the $\mathrm{IO}_{3}^{-}$treatment at 0,50 , 100,200 , and $500 \mu \mathrm{mol} \mathrm{L}{ }^{-1}$, iodate reduction activity was measured. Data are mean \pm standard error $(n=3)$. Bars with the same letter are not significantly different among each iodine treatments (Tukey's multiple range test, $P<0.05)$. (B) Concentration of total iodine in shoots and roots of rice, barley and soybean after the $1 \mathrm{O}_{3}^{-}$treatment. Data are mean \pm standard error $(n=3)$. 

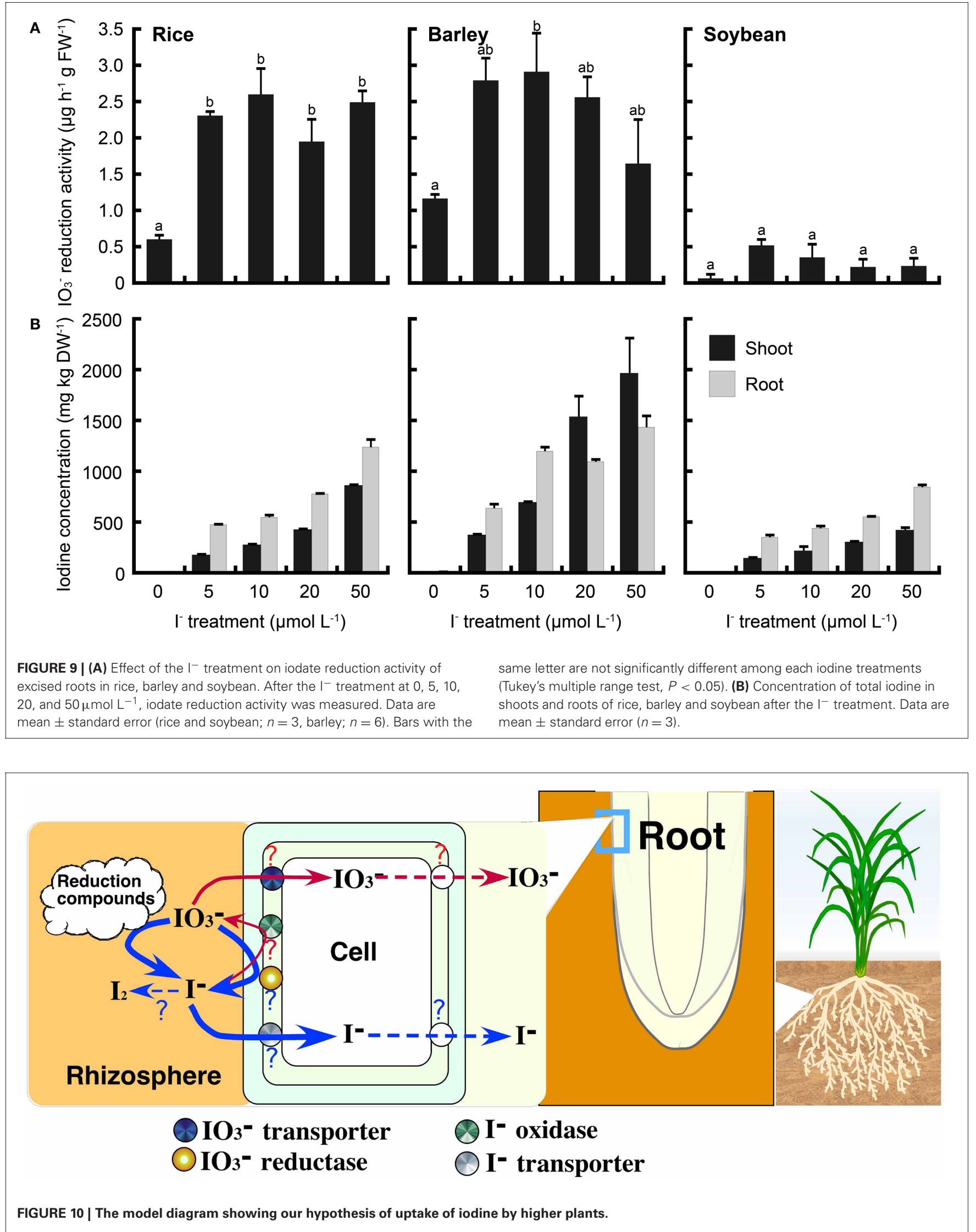
to reduce $\mathrm{IO}_{3}^{-}$to $\mathrm{I}^{-}$. Earlier, a report stated that when grown at similar iodine levels, $\mathrm{I}^{-}$-treated plants had a higher iodine content than $\mathrm{IO}_{3}^{-}$-treated plants (Muramatsu et al., 1983; Mackowiak and Grossl, 1999; Zhu et al., 2003; Weng et al., 2008a; Voogt et al., 2010). Our results suggest that plants would take up $\mathrm{I}^{-}$reduced from $\mathrm{IO}_{3}^{-}$.

\section{EFFECT OF IODINE EXCESS ON RICE SHOOTS AND ROOTS}

From our observations, the concentration of iodine in our $\mathrm{I}^{-}$ treatment that caused adverse effects on growth of both the sensitive and tolerant cultivars was much lower than that of our $\mathrm{IO}_{3}^{-}$treatment (Tables 1, 2). This result is consistent with previous reports in the literature (Umaly and Poel, 1971; Mackowiak and Grossl, 1999; Zhu et al., 2003; Weng et al., 2008a). Plant height decreased with high iodine treatment in both the soil culture and water culture (Figures $\mathbf{1 A - C}, \mathbf{A 1 A}$, Tables 1, 2). On the other hand, root length was not significantly affected, although root fresh weight decreased under the high iodine treatment, especially $\mathrm{I}^{-}$excess. This may in part have been due to the age of the treated plants. Also, the emergence of new roots appeared to be suppressed at high iodine levels in the growth solutions. Decrease in root fresh weight is related to the inhibition of elongation of new roots. High iodine levels would also inhibit the elongation of roots as with any other excessive nutrient condition.

\section{IODINE CONCENTRATION IN PLANT BODY AND TOLERANCE TO IODINE EXCESS}

Under the water-cultured condition, iodine concentration in the shoots of "Gohyakumangoku" (tolerant) was higher than that of "Nipponbare" (sensitive) in both the $\mathrm{IO}_{3}^{-}$and $\mathrm{I}^{-}$ treatments (Figures 5B, 6B, A1B). On the other hand, under the soil-cultured condition, iodine concentration in the shoots of "Gohyakumangoku" (tolerant) was lower than that of "Nipponbare" (sensitive) in the $\mathrm{IO}_{3}^{-}$treatments (Figure 1D). However, "Gohyakumangoku" showed higher tolerance to excess iodine than "Nipponbare" regardless of iodine concentration in shoots under both conditions. Yamada et al. (2006) also reported that iodine concentration in shoots of "Gohyakumangoku" was much lower than that of "Nipponbare" under soil culture. The discrepancy between these results was considered due to the different culture condition employed, namely soil-cultured (Figure 1D) or water-cultured (Figure 5B). Therefore, it is considered that the tolerance levels among three rice cultivars to excess iodine had no obvious relation to iodine concentration in shoots. In our study, higher iodine concentration in "Gohyakumangoku" (tolerant) shoots suggests that the form or localization of iodine within the plant body is more important than the total concentration of iodine. The higher tolerance of "Gohyakumangoku" to iodine stress might correlate with the species of iodine transported or stored within the plant body (e.g., vacuole and intercellular space).

\section{INDUCTION OF IODATE REDUCTION ACTIVITY IN RESPONSE TO EXTERNAL IODINE}

Iodate reduction activity displayed by "Nipponbare" and "Gohyakumangoku" roots increased with either $\mathrm{IO}_{3}^{-}$or $\mathrm{I}^{-}$ treatment. In "Gohyakumangoku," iodate reduction activity decreased at concentrations of iodine that resulted in visible iodine-toxicity symptoms (Figures 5A, 6A).

The induction of iodate reduction by $\mathrm{I}^{-}$treatment was an unexpected phenomenon since our original hypothesis predicted that plants would take up $\mathrm{I}^{-}$reduced from $\mathrm{IO}_{3}^{-}$. The mechanism of this induction is still unclear. Unidentified oxidation of $\mathrm{I}^{-}$might be related to this induction since the oxidation activity of roots detected by $\partial$-naphtylamine was also increased by iodine treatment (data not shown).

The decrease in iodate reduction under high iodine conditions seems to correlate with iodine tolerance. Because lower iodate reduction activity will be helpful under excess iodine condition since high iodate reduction activity can contribute to uptake of $\mathrm{I}^{-}$, more toxic form of iodine. Lower concentration of iodine in roots of "Gohyakumangoku" might be related to lower iodate reduction activity in $\mathrm{I}^{-}$treatment. Further detailed studies are needed to fully clarify these responses.

However, our results suggest that iodate reduction in rice roots is related, at least in part, to external iodine conditions. The induction of iodate reduction activity in $\mathrm{IO}_{3}^{-}$treatment was suppressed by removing iodine from culture media (data not shown). We also demonstrated that barley and soybean roots converted $\mathrm{IO}_{3}^{-}$to $\mathrm{I}^{-}$, and that iodate reduction activity of barley and soybean roots increased with both $\mathrm{IO}_{3}^{-}$and $\mathrm{I}^{-}$ treatment (Figures 8, 9).

\section{THE MECHANISM OF UPTAKE AND TRANSPORT OF IODINE IN PLANTS}

This is the first report demonstrating that plant roots have an ability to reduce $\mathrm{IO}_{3}^{-}$to $\mathrm{I}^{-}$and that iodate reduction activity in roots could respond to external iodine. We show our hypothesis of uptake of iodine by roots in Figure 10. Conversion of $\mathrm{IO}_{3}^{-}$to $\mathrm{I}^{-}$by the excised roots suggests the existence of iodate reductase in roots. Iodate would be reduced by iodate reduction compounds released from the roots treated with iodine (data not shown). Under excess iodine condition, it is considered that $\mathrm{I}^{-}$is mainly absorbed by roots due to high iodate reduction activity of iodate reductase. The existence of iodate reductase induced by iodine would be suggested by the induction of iodate reduction activity of crude proteins extracted from rice roots treated with iodine (data not shown). Iodide oxidase might also exist and be related to the iodate reduction in $\mathrm{I}^{-}$treatment. The uptake of iodine could be regulated by transporters in plasma membrane. Transport of iodine from roots to shoots could be also regulated by transporters. In barley treated with higher $\mathrm{I}^{-}$, iodine concentration in shoots reversed that of roots. In $\mathrm{IO}_{3}^{-}$treatment, iodine concentration in shoots was higher than that of roots only in barley. These results suggest the existence of iodine transporters. The major chemical form of soluble iodine in soil solutions is $\mathrm{I}^{-}$under flooded conditions (Muramatsu et al., 1989; Yuita, 1992) and $\mathrm{IO}_{3}^{-}$under non-flooded conditions (Yuita, 1992). Soybean and barley showed the difference in the iodate reduction activity and iodine concentrations in plant body between in $\mathrm{I}^{-}$and $\mathrm{IO}_{3}^{-}$treatment. This might suggest the difference in the mechanism of uptake and transport of iodine between paddy-rice and upland crops. 


\section{REFERENCES}

Baba, I., Inada, K., and Tajima, K. (1964). "Mineral nutrition and the occurrence of physiological diseases," in The Mineral Nutrition of the Rice Plant, ed IRRI (Baltimore, MD: The Johns Hopkins Press), 173-195.

Böszörményi, Z., and Cseh, E. (1960). The uptake and reduction of iodate by wheat-roots. Curr. Sci. 29, 340-341.

Cao, X. Y., Jiang, X. M., Kareem, A., Dou, Z. H., Abdul Rakeman, M., Zhang, M. L., et al. (1994). Iodination of irrigation water as a method of supplying iodine to a severely iodine-deficient population in Xinjiang, China. Lancet 344, 107-110. doi: 10.1016/S01406736(94)91286-6

De Benoist, B., Andersson, M., Egli, I., Takkouche, B., and Allen, H. (Eds). (2004). "Iodine status worldwide," in WHO Global Database on Iodine Deficiency, (Geneva: World Health Organization), 12-13.

Hong, C. L., Weng, H. X., Yan, A. L., and Islam, E. U. (2009). The fate of exogenous iodine in pot soil cultivated with vegetables. Environ. Geochem. Health 31, 99-108. doi: 10.1007/s10653-008-9169-6

Mackowiak, C. L., and Grossl, P. R. (1999). Iodate and iodide effects on iodine uptake and partitioning in rice (Oryza sativa L.) grown in solution culture. Plant Soil 212, 135-143. doi: 10.1023/A:1004666607330

Muramatsu, Y., Christoffers, D., and Ohmomo, Y. (1983). Influence of chemical forms on iodine uptake by plant. J. Radiat. Res. 24, 326-338. doi: 10.1269/jrr.24.326
Muramatsu, Y., Uchida, S., Sumiya, M., Ohmomo, Y., and Obata, H. (1989). Tracer experiments on transfer of radio-iodine in the soil-rice plant system. Water Air Soil Pollut. 45, 157-171. doi: 10.1007/BF00208585

Tagami, K., Uchida, S., Hirai, I., Tsukada, H., and Takeda, H. (2006). Determination of chlorine, bromine and iodine in plant samples by inductively coupled plasma-mass spectrometry after leaching with tetramethyl ammonium hydroxide under a mild temperature condition. Anal. Chim. Acta 570, 88-92. doi: 10.1016/j.aca.2006.04.011

Tensho, K. (1970). lodine and bromine in soil-plant system with special reference to "Reclamation-Akagare Disease" of lowland rice. Jpn. Agric. Res. Q. 5, 26-32.

Umaly, R. C., and Poel, L. W. (1971). Effects of iodine in various formulations on the growth of barley and pea plants in nutrient solution culture. Ann. Bot. 35, 127-131.

Voogt, W., Holwerda, H. T., and Khodabaks, R. (2010). Biofortification of lettuce (Lactuca sativa L.) with iodine: the effect of iodine form and concentration in the nutrient solution on growth, development and iodine uptake of lettuce grown in water culture. J. Sci. Food Agric. 90, 906-913. doi: 10.1002/jsfa.3902

Watanabe, I., and Tensho, K. (1970). Further study on iodine toxicity in relation to "Reclamation Akagare" disease of lowland rice. Soil Sci. Plant Nutr. 16, 192-194. doi: 10.1080/00380768.1970.10432839

Weng, H. X., Hong, C. L., Yan, A. L., Pan, L. H., Qin, Y. C., Bao, L. T., et al. (2008a). Mechanism of iodine uptake by cabbage: effects of iodine species and where it is stored. Biol. Trace Elem. Res. 125, 59-71. doi: 10.1007/s12011-008-8155-2

Weng, H. X., Weng, J. K., Yan, A. L. Hong, C. L., Yong, W. B., and Qin, Y. C. (2008b). Increment of iodine content in vegetable plants by applying iodized fertilizer and the residual characteristics of iodine in soil. Biol. Trace Elem. Res. 123, 218-228. doi: 10.1007/s12011-008-8094-y

Yamada, H., Onagawa, Y., Adachi, T., Takahashi, K., and Yonebayashi, K. (2006). Relationship between soil iodine and "Akagare" disease of rice plant. Jpn. J. Soil Sci. Plant Nutr. 77, 563-568.

Yamada, H., Takeda, C., Mizushima, A., Yoshino, K., and Yonebayashi, K. (2005). Effect of oxidizing power of roots on iodine uptake by rice plants. Soil Sci. Plant Nutr. 51, 141-145. doi: 10.1111/j.17470765.2005.tb00018.x

Yonehara, N., Kozono, S., and Sakamoto, H. (1991). Flow injection-spectrophotometric determination of trace amounts of iodide by its catalytic effect on the 4, 4'-bis (dimethylamino)diphenylmethane-Chloramine $\mathrm{T}$ reaction. Anal. Sci. 7, 229-234.

Yoshida, S., Muramatsu, Y., Katou, S., and Sekimoto, H. (2007). Determination of the chemical forms of iodine with IC-ICP-MS and its application to environmental samples. J. Radioanal. Nucl. Chem. 273, 211-214. doi: 10.1007/s10967-007-0738-4

Yuita, K. (1992). Dynamics of iodine, bromine, and chlorine in soil, II: chemical forms of iodine in soil solutions. Soil Sci.
Plant Nutr. 38, 281-287. doi: 10.1080/00380768.1992.10416491

Zhu, Y. G., Huang, Y. Z., Hu, Y., and Liu, Y. X. (2003). Iodine uptake by spinach (Spinacia oleracea L.) plants grown in solution culture: effects of iodine species and solution concentrations. Environ. Int. 29, 33-37. doi: 10.1016/S0160-4120 (02)00129-0

Conflict of Interest Statement: The authors declare that the research was conducted in the absence of any commercial or financial relationships that could be construed as a potential conflict of interest.

Received: 16 February 2013; accepted: 10 June 2013; published online: 10 July 2013.

Citation: Kato S, Wachi T, Yoshihira $K$, Nakagawa T, Ishikawa A, Takagi D, Tezuka A, Yoshida H, Yoshida S, Sekimoto $H$ and Takahashi $M$ (2013) Rice (Oryza sativa L.) roots have iodate reduction activity in response to iodine. Front. Plant Sci. 4:227. doi: 10.3389/fpls. 2013.00227

This article was submitted to Frontiers in Plant Physiology, a specialty of Frontiers in Plant Science.

Copyright (c) 2013 Kato, Wachi, Yoshihira, Nakagawa, Ishikawa, Takagi, Tezuka, Yoshida, Yoshida, Sekimoto and Takahashi. This is an open-access article distributed under the terms of the Creative Commons Attribution License, which permits use, distribution and reproduction in other forums, provided the original authors and source are credited and subject to any copyright notices concerning any third-party graphics etc. 


\section{APPENDIX}

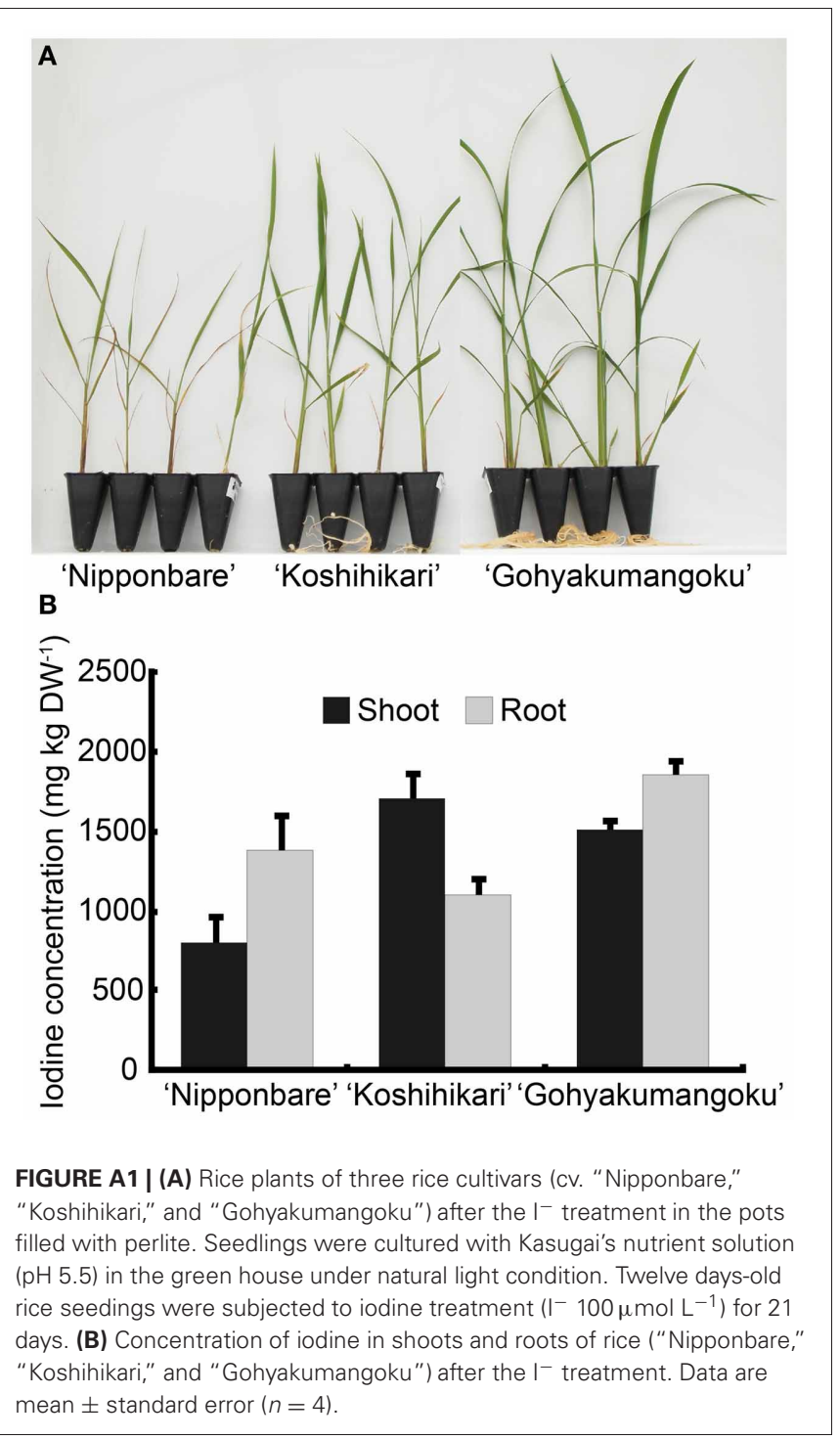

